\title{
Gambaran Apraisal Sikap dalam Teks Dialog Penyandang Anxiety
}

\author{
Author: \\ Suriyadi ${ }^{1}$ \\ Erwinsyah $^{2}$ \\ Sulaiman Ahmad ${ }^{3}$ \\ Afiliation:
Politeknik Negeri
Medan $^{1,2,3}$
}

Corresponding email

Suriyadi

Histori Naskah:

Submit: 2022-02-23

Accepted: 2022-02-23

Published: 2022-02-23

This is an Creative Commons License This work is licensed under a Creative Commons Attribution-NonCommercial 4.0 International License

\begin{abstract}
Abstrak:
Penelitian bahasa evaluatif dalam teori Apraisal ini menggambarkan makna yang terdapat dalam teks dialog para penyandang ansietas (anxiety) dalam grup ByeBye Cemas 3 (BBC3) yang dapat berupa sumber-sumber bahasa yang tidak hanya memiliki nilai negatif tetapi juga bersumber dari bahasa-bahasa yang memiliki nilai positif. Tujuan penelitian ini adalah (1) untuk memerikan apraisal Sikap dalam teks dialog penyandang anxiety dan (2) menganalisis apraisal Sikap yang terbentuk dalam teks dialog penyandang Anxiety.

Metode penelitian yang digunakan adalah penelitian deskriptif analitis. Data yang bersumber dari teks dialog penyandang anxiety di grup whatsApp BBC3 dikumpulkan, dikelompokkan dan dianalisis berdasarkan data apa adanya yang dikomunikasikan oleh para penyandang anxiety.

Berdasarkan analisis data disimpulkan: (1) penggunaan sumber-sumber subsistem Afek dalam apraisal Sikap paling dominan dibandingkan dengan kedua subsistem lainnya yaitu Penghakiman/Penilaian dan Apresiasi. (2), penggunaan sumbersumber "takut" bernilai negatif paling dominan dalam subsistem Afek, kemudian diikuti sumber-sumber "ingin/hasrat" yang bernilai positif. Setelah itu, penggunaan sumber-sumber "kapasitas" bernilai possitif paling dominan dalam subsistem Penilaian/Penghakiman, kemudian diikuti sumber-sumber "tenasitas" yang bernilai negatif. Penggunaan sumber-sumber "kualiatas" bernilai positif paling dominan dalam subsistem Afek, kemudian diikuti sumber-sumber "valuasi" yang bernilai negatif. Dominasi penggunaan leksis subsistem Afek dalam percakapan para penyandang anxiety di WhatsApp BBC pada umumnya disebabkan para penyandang anxiety berbicara tentang ekspresi emosi dan perasaan mereka berkaitan dengan penyakit cemas dan takut yang menerpa mereka.
\end{abstract}

Kata kunci: Bahasa penyandang anxiety, Apraisal Sikap, Afek, Penghakiman, Apresiasi

\section{Pendahuluan}

Satu di antara masalah asas yang selalu dibahas dalam kajian teks adalah bahwa mesej yang diungkapkan oleh pengarang atau penutur mempunyai sumber makna positif atan negatif, subjektivitas atau objektivitas dari rangkaian kata dalam tulisan atau ujaran yang diucapkannya. Interaksi sosial dalam komunikasi ini memberi petunjuk adanya bahasa evaluatif yang menunjukkan nilai positif atau negatif di dalam teks dialog atau teks tulis dalam interaksi sosial antara manusia. Dalam konteks ini penutur atau penulis menggambarkan sesuatu yang diutarakannya atau dituliskannya apakah kata-kata atau frasa dalam klausa yang dituturkan atau ditulis rnerupakan perasaan sedih, senang, rnenderita, bingung, dan sebagainya.

Fenomena bahasa di atas dapat dilihat pada bahasa penyandang penderita ansietas (anxiety) yang merupakan orang-orang yang sepintas kelihatannya sehat jika dipandang dari postur fisiknya dan rnerupakan orang-orang yang normal, sehat, dan baik-baik saja. Namun, sesungguhnya dalam diri 


\section{JBS|Juraral Bathase \& Sastra Ind onesia}

Volume: 1 | Nomor 1 | November 2021 | E-ISSN: 2809-238X | DOI: 10.47709/jbsi.v1i1.1394

mereka tersimpan kecemasan atau ketakutan yang berlebihan yang tidak akan terlihat dari perilaku mereka sehari-hari. Penyandang anxiety kelihatan memang sakit jika rnereka diperhatikan dengan lebih seksama lagi bahwa rnereka itu sesungguhnya rnenderita gangguan cemas atau takut yang tak beralasan.

Kegelisahan adalah ketakutan yang tidak disadari oleh adanya sumber ketakutan yang jelas (tidak rasional) sementara ketâkutan adalah rasional kerana objek yang ditakutkan itu wujud (Andri 2017: 10).

Kecemasan yang terjadi pada rnanusia ternyata memiliki dampak juga terhadap bahasa yang digunakannya dalam berinteraksi sosial dengan orang lain. Dialog berikut ini menunjukkan pernyataan di atas yang berupa teks lisan yang dituliskan dari percakapan melalui WhatsAp (WA) Bye Bye Cemas (BBC) antara dua orang penderita anxiety di bawah ini.

Melani: Malam Pak. Saya sudah lama minum obat racik dari dokter Pak

Yoga : Malam Bu Melani

Melani: Apa Bapak pernah mengalami cemas? Cemas dan panik

saya sedang tinggi Pak

Yoga : Saya bahkan minum lebih lama dari Ibu.

Teks dialog di atas menunjukkan bahwa kedua orang itu menderita suatu gangguan atau penyakit yang tidak mereka jelaskan. Namun, dari frasa yang diucapkan Malam Pak. Saya sudah lama minum obat racik dalam klausa Malam Pak. Saya sudah lama minum obat racik dari dokter Pak menunjukkan perasaan khawatir tentang kesehatan yang dialami Melani.

Frasa sudah lama minum obat racik dalam bahasa evaluatif menunjukkan sumber-sumber bahasa yang mengandung nilai negatif yang tercermin dalam kondisi kesehatan Melani. Obat racik dalam konteks frasa ini bermakna beberapa obat antidepresan yang diolah menjadi satu campuran, biasanya dimasukkan dalam kapsul, yang diberikan psikiater atau konsultan psikosomatik kepada para pasiennya.

Selanjutnya, Melani juga bertanya tentang cemas dan panik dalam Apa Bapak pernah mengalami cemas? Cemas dan panik saya sedang tinggi Pak menunjukkan sumber-sumber bahasa yang juga mengandung nilai negatif.

Hal yang sama juga diutarakan Yoga bahwa Saya bahkan minum lebih lama dari Ibu memiliki sumbersumber hahasa yang juga mengandung nilai negatif. Frase minum lebih lama dalam konteks dialog atau percakapan ini juga menggambarkan bahwa klausa yang diutarakan oleh Yoga juga memiliki surnbersurnber bahasa yang negatif daripada positif.

Uraian di atas menggambarkan suatu fakta bahwa makna isi dari percakapan antara Melani dan Yoga tidak hanya terfokus pada masalah subjektivitas atau objektivitas mereka saja tetapi juga terlihat penilaian teks terhadap sumber-sumber makna bahasa yang berhubungan dengan rangkaian leksis dalam susunan klausa dalam bahasa evaluatif yang dapat memiliki sumber-sumber bahasa yang positif dan negatif. Penilaian sumber-sumber bahasa positif dan negatif ini bergantung pada konteks di mana leksis itu berada.

Bahasa penilaian merujuk kepada aksi penilaian yang menggunakan stansial (pengambilan sikap) (DuBois, 2007). Bahasa penilaian berkaitan dengan atitud seseorang kepada orang, keadaan, atau entitas lain, secara subjektif dan terkandung dalam sistim nilai dalam masyarakat itu (Huston, 1994). 
Dari percakapan antara Melani dan Yoga terlihat dengan jelas adanya suatu proses sosial yang menggambarkan interaksi bahasa di antara kedua orang tersebut. Brown \& Yule (1983) dan Halliday (1994) menjelaskan pemakaian bahasa sebagai bahagian daripada sistem dan budaya masyarakat yang menggunakan bahasa tersebut. Penggunaan bahasa bukan sekedar alat komunikasi, pengguna bahasa dalam komunikasi itu sendiri adalah terkait dengan pesan itu sendiri. Brown \& Yule (1983) menyebutnya dengan transactional \& interpersonal. Sementara, Haliday (1994/2004) menyebutnya dengan ideational \& interpersonal. Istilah transaksional \& ideational merujuk kepada fungsi bahasa untuk memberi sinyal komunikasi. Terma transaksional \& ideational merujuk kepada fungsi bahasa untuk menghantar mesej komunikasi. Sementara, fungsi bahasa untuk membuat relasi sosial dalam komunikasi disebut interpersonal. Hubungan sosial yang didasarkan atas penggunaan bahasa evaluatif terlihat fungsinya dalam konteks yang menunjukkan kebahagiaan, kesedihan, kecemasan, ketakutan, kegembiraan, dan lainlain seperti yang dijelaskan di atas.

Merujuk pada permasalahan di atas, kajian ini merupakan suatu kajian untuk menginvestigasi apraisal Sikap yang merupakan bagian dari bahasa evaluatif pada bahasa teks lisan yang dituliskan melalui WhatsApp BBC. Lebih spesifik lagi, kajian ini bertujuan untuk melihat sumber-sumber Sikap yang meliputi afek (affect), penghakiman (judgement), dan apresiasi (appreciation). Dengan demikian, melalui penelitian ini, gambaran Sikap (attitude) dari bahasa para penyandang anxiety dalam WhatsApp BBC dapat terlihat dengan jelas.

Dari deskripsi di atas pertanyaan-pertanyaan dalam permasalahan penyelidikan ini dapat dirumuskan sebagai berikut: 1) Bagaimana apraisal Sikap dalam teks percakapan penyandang anxiety? 2) Mengapa apraisal Sikap terbentuk demikian dalam teks dialog penyandang anxiety?

Penyelidikan ini membatasi diri hanya pada penelitian sumber-sumber bahasa apraisal Sikap yang memiliki subkategori afek (affect), penghakiman (judgement), dan apresiasi (appreciation) pada dialog WhatsApp Bye-Bye Cemas (BBC). Sementara, Sumber-sumber Apraisal lainnya seperti pemosisian (engagement) dan graduasi (graduation) tidak menjadi fokus dalam penelitian.

\section{Studi Literatur}

Dalam penelitian ini, teori Apraisal (Martin 2004, Martin \& White 2005 dan Martin \& Rose 2007) digunakan untuk menunjukkan gambaran sikap para penyandang anxiety yang saling berinteraksi sosial dalam WhatsApp BBC.

\section{Teori Apraisal}

Read dkk (2008) menjelaskan bahwa Apraisal adalah teori bahasa penilaian yang dibentangkan dalam budaya linguistik sistemik fungsional. Konteks Appraisal menerangkan taksonomi jenis bahasa yang dipakai untuk mengaitkan penilaian dan kedudukan seseorang.

Konteks untuk meneliti, mendeskripsikan, dan menerangkan bagaimana bahasa dipakai untuk menilai, memakai stantial, membina teks pribadi, dan mengurus hubungan kedudukan dan interpersonal disebut Apraisal (Martin dan White, 2005).

\section{Sikap}




\section{JBST}

Volume: 1 | Nomor 1 | November 2021 | E-ISSN: 2809-238X | DOI: 10.47709/jbsi.v1i1.1394

Teori apraisal memiliki tiga subkategori yaitu sikap (attitude), pemosisian (engagement), dan graduasi (graduation). Dua dari tiga subkategori dalam kajian ini tidak dikaji yaitu Pemosisian dan Graduasi. Dengan demikian, sumber-sumber yang dikaji hanya apraisal Sikap.

Sikap, menurut Martin dan White (2005: 35), adalah suatu tinjauan terhadap kiat orang menyatakan kondisi. Apraisal Sikap ini memiliki tiga subsistem antara lain, Afek (affect), Penghakiman (judgement), dan Apresiasi (appreciation). Afek, Penghakiman, dan Apresiasi ini memiliki turunan kajian yang bervariasi.

Pertama, Afek dipakai buat membahas ekspresi emosi dan perasaan. Afek berkaitan pada resors yang mengungkapkan perasaan positif maupun negatif, melihat orang itu bahagia ataupun murung, merasa percaya ataupun khawatir, terpukau ataupun jenuh.

Di bidang jenisnya, Afek mempunyai empat subgolongan yakni nir/inklisasi (dis/inclination), ketidak/kebahagiaan (un/happiness), ketidak/keamanan (insecurity), dan ketidakpuasan (dissatisfaction). Dilihat dari bentuk polaritasnya, Afek mempunyai dua subkelas antara lain kutub positif serta negatif. Di samping itu, Afek juga diklasifikasikan pula ke dalam kaidah serta kualitas.

Contoh:

Keceriaan/ketidakceriaan:

\section{Indira merasa ceria/sedih.}

Keterjaminan/ketidakterjaminan:

\section{Indira merasa yakin/cemas.}

Kepuasan/ketidakpuasan:

\section{Indira merasa asyik/jemu.}

Kedua, Martin \& White (2005) menyatakan penghakiman sebagai area arti yang menunjuk kepada atitud seseorang kepada orang lain serta perilaku dan karakternya. Penghakiman biasanya terbagi atas dua jenis yaitu, 1) berkaitan dengan social esteem dan social sanction.

Penghakiman penghargaan sosial berhubungan dengan normality (lazim atau tidaklazim orang itu), capacity (mampu atau tidak mampu orang itu) dan tenacity (tegas atau tidak tegasnya orang itu). Penghakiman sanksi sosial bertalian dengan veracity (jujur atau tidak jujur orang itu) dan propriety (etis atau tidak etis seorang itu).

Selain itu, pola modalizasi dipakai buat mengetahui kriteria evaluasi (Haliday 1985,1994, Haliday \& Matthissen 2004). Normaliti menunjukkan pada kelaziman, kapasiti menunjukkan kapabilitas, tenasiti menunjukkan tendensi atau angan-angan, verasiti menunjukkan probabilitas, dan proprieti menunjukkan keharusan.

Berdasarkan Martin dan White (2005: 54) awal mula proposisi, sistematis realisasi boleh diruntut guna mengungkapkan posibilitas, kelaziman, serta kapasiti yang diawali degan relasi yang kongruen serta melanjutkan ke format metafora mengarah kepada kata dengan jelas terbagi alamiah. 
Martn \& White (2005) menjelaskan modalisasi probabilatas dalam modus bisa dikaitkan pada evaluasi verasiti.

Contoh:

\section{Ita cantik.}

2. Ita tentu cantik

3. Ita benar-benar cantik.

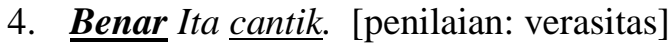

Ketiga, Apresiasi lazimnya terbagi atas perhatian kita kepada entitas (entitas meraih atensi kita, entitas itu membuat kita senang), stuktur entitas itu (sebanding atau berbelit-belit), serta kualitas entitas itu(pembaharuan, asli, dll) Martin dan White (2005: 56)

Lebih lanjut, Martin dan White (2005) membagi parameter Apresiasi menjadi lima kategori, yaitu dampak (impact), kualitas (quality), keseimbangan (balance), kompleksitas (complexity), dan valuasi (valuation). Sama halnya dengan Afek dan Penilaian, Apresiasi juga memiliki dua polaritas yaitu positif dan negatif.

\section{Bahasa Penyandang Anxiety}

Bahasa para penyandang anxiety dalam praktiknya memiliki persamaan dengan bahasa orang-orang pada umumnya. Perbedaannya terletak pada penggunaan bahasa yang selalu menggambarkan kecemasan dan ketakutan yang terus- menerus. Oleh karena itu, leksis yang kemungkinan muncul pada penyandang anxiety adalah bahasa yang memiliki sumber-sumber bentuk nilai negatif daripada bentuk nilai positif seperti yang sudah dipaparkan pada dialog antara Yoga dan Melani dalam latar belakang penelitian.

Penjelasan lain tentang anxiety dikemukan oleh Nevid dkk (2014: 158-9) bahwa anxiety adalah keadaan ketakutan atau firasat umum. Kecemasan berguna karena memotivasi kita untuk melaksanakan pemeriksaan kesehatan secara berkesinambungan atau memotivasi kita untuk belajar lebih giat lagi. Itulah sebabnya, ketakutan itu adalah tanggapan yang standar pada gertakan, namun ketakutan sebagai tidak normal jika tidak proporsional dengan realitas ancaman, atau ketika tampaknya muncul begitu saja — yaitu, ketika bukan sebagai respons terhadap peristiwa kehidupan.

Lebih lanjut, Nevid dkk (2014: 158-9) menjelaskan reaksi kecemasan dapat menimbulkan emosi yang signifikan kesusahan atau gangguan kemampuan seseorang untuk berfungsi, disebut sebagai gangguan kecemasan. Kegelisahan, benang merah yang menghubungkan berbagai jenis gangguan kecemasan, bisa dialami dengan cara yang berbeda, dari ketakutan intens yang terkait dengan serangan panik hingga yang umum firasat atau kekhawatiran dalam gangguan kecemasan umum.

Kecemasan, menurut Nevid dkk (2014: 159), diidentifikasi melalui beragam gejala yang melintasi fisik, atitud,dan domain psikologis:

a) Ciri tubuh mungkin termasuk kecemasan, bergetar, manggah di ulu hati maupun dada, keringat deras, punggung tangan berpeluh, kliyengan ataupun kolaps, kekeringan dimulut atau tenggorokan, sesak napas, jantung berdebar-debar, jari atau tungkai dingin, dan sakit perut atau mual. 


\section{JBST}

Volume: 1 | Nomor 1 | November 2021 | E-ISSN: 2809-238X | DOI: 10.47709/jbsi.v1i1.1394

b) Ciri-ciri perilaku dapat mencakup perilaku penghindaran, kemelekatan atau atitud terikat, dan perilaku cemas.

c) Ciri-ciri kognitif mungkin termasuk kecemasan, rasa cemas ataupu ketakutan yang menghantui masa depan, keasyikan atau kesadaran yang kuat terhadap sensasi tubuh, kekhawatiran lepas kendali, memikirkan pikiran yang tidak stabil yang terus menerus, campur aduk atau pikiran jadi bingung, sulitan berkonsentrasi atau memfokuskan pikiran dan berpikir bahwa hal-hal menjadi di luar kendali.

Berdasarkan uraian di atas, kelihatan bahwa penyandang anxiety memiliki beberapa faktor yang menjadi penyebab berubahnya leksis dalam interaksi komunikasi mereka. Kecemasan yang memiliki gejala fisik, perilaku dan domain kognitif, seperti yang diuraikan Nevid dkk di atas bisa menjadi penyebab perubahan dalam pemilihan bahasa.

\section{Metode Penelitian}

Metode yang digunakan dalam penelitian ini adalah metode deskriptif Analitis. Metode ini digunakan untuk mencari unsur-unsur, ciri-ciri, sifat-sifat suatu fenomena, Metode ini dimulai dengan mengumpukan data, menganalisis data, dan kemudian menginterprestasinya.

\section{Subjek penelitian}

Subjek penelitian ini adalah bahasa yang digunakan oleh para penyandang gangguan anxiety dalam berkomunikasi antara sesama teman sependeritaan pada grup WhatsApp BBC.

\section{Rancangan Penelitian}

Tahap-tahap penelitian yang dilaksanakan sebagai berikut:
a. menemukan gap permasalahan dalam latar belakang;
b. merumuskan masalah dan tujuan penelitian;
c. melakukan kajian literatur untuk menrinci permasalahan yang menjadi fokus kajian;
d. menentukan metode penyediaan sumber yang sah serta kredibel;
e. menyediakan data yang sah serta terandal;
f. menentukan metode analisis data;
g. melakukan analisis data;
h. menyajikan hasil analisis data;
i. melakukan pembahasan hasil analisis data;
j. menarik simpulan; 


\section{Hasil}

Data yang dikumpulkan dari kumpulan dialog atau percakapan antara para penyandang anxiety yang menggunakan media WhatsApp BBC. Melalui penggunaan piranti apraisal Sikap diperoleh hasil data sebagai berikut.

\section{Pola Sikap:afek:inklinasi:ketakutan}

Tabel 1 Leksis "cemas"

\begin{tabular}{rrrr}
\hline 1. & perut kyk lemas, ujungya cemas & cemas & /FN: Tpi saya merasa uda mndingan \\
2. & UGD..tp stlh baca buku bye2 & cemas & 90 persen ilang../ \\
cemas.. & & \\
\hline
\end{tabular}

\section{Pola Sikap:afek:inklinasi:keinginan/hasrat}

Tabel 2 Leksis "baik"

3. smngat/ELT: Semua hasilnya baik terakhir desember kmrn dianjurkan

4. hasil rontgen leher hasilnya baik jd mau lihat di kepala lagi

\section{Pola Sikap:afek:ketidakbahagiaan:sengsara}

Tabel 3 Leksis "sedih"

5. langkah aja ga kuat,sampe sy sedih bgt knp sy yg tadinya kuat

6. ngemall $\mathrm{n}$ phobia2 lainnya. sedih rasanya/Jimmy (JM): Obat

\section{Pola Sikap:afek:ketidakbahagiaan:antipati/tidak peduli}

Tabel 4 Leksis "benci"

\begin{tabular}{|l|c|l|l|}
\hline 7. & keluarkan kata2 yg membuat sy & benci & dg pikiran yg negatif. Contoh \\
\hline 8. & deh, guru ngga bener bener & benci & dengan memancing kan ? / \\
\hline
\end{tabular}

\section{Pola Sikap:afek:kebahagian:ceria}

Tabel 5 Leksis "senang"

9. suka berbaur bersosial/Saya senang dengan keadaan apapun /

10. ..kt saling mendukung $\mathrm{n}$ senang punya teman2 seperjuangan

\section{Pola Sikap:afek:kebahagian:kasih}

Tabel 6 Leksis "Suka"

11. pagi n MLM pas mau tidur...yg suka sesek TGH MLM JD enak..klu

12. tapi, karna anxiety nya suka mampir mampir. lambung masih

Pola Sikap:afek:ketidakpuasan:bosan

Tabel 7 Leksis "Sesak"

\begin{tabular}{lcll}
\hline 13. & 02..bln 1 UGD..krn cemas n & sesak... & tp bgtu baca buku bye2 \\
14. & cemas...ak tantangin cemas n & sesaknya & sekuat ap sih sensasinya \\
\hline
\end{tabular}

\section{PolaSikap:afek:ketidakpuasan:tidak senang}

Tabel 8 Leksis "marah"

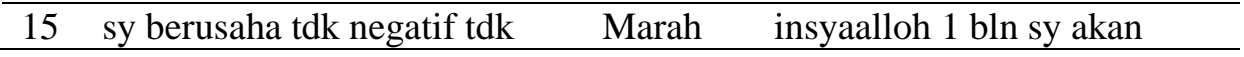

Pola Sikap:afek:kepuasan:menarik hati

Tabel 9 Leksis "indah"

16 MN: Smangat bu ingat yg indah2 yg pernah ibu lakukan, ingat




17 kasih Kehidupan ini Begituu $\quad$ Indah $\quad$ dan Luar Biasa ?? Tuhan menghendaki

\section{Pola Sikap:afek:kepuasan:senang}

Tabel 10. Leksis "bahagia"

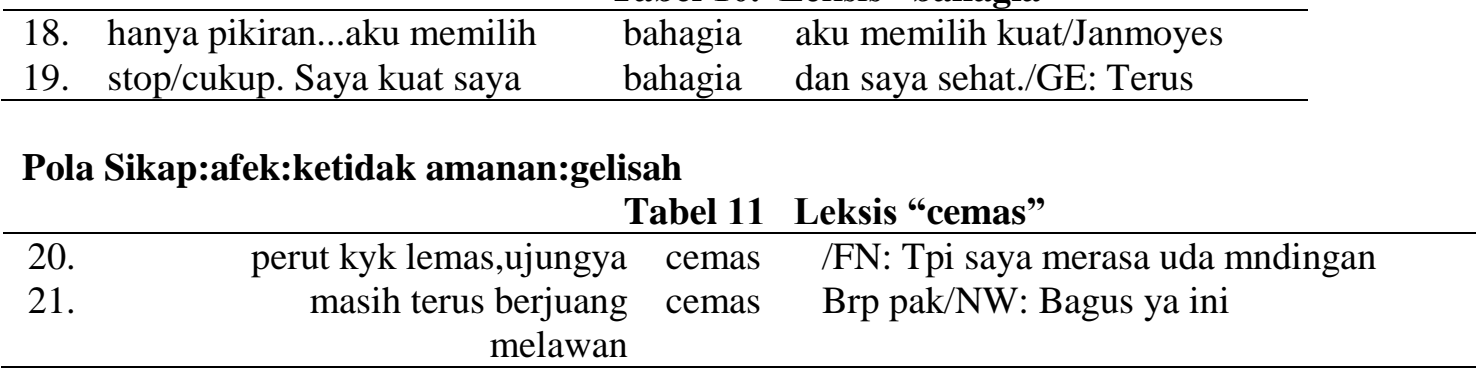

Pola Sikap:afek:ketidakamanan:heran

Tabel 12 Leksis "Pusing"

22. rasa g karu2an itu/MJ: Sampe pusing sya/MJ: Apa ada yg merasakn

23. itu dada deg2an, gemetar,kpla pusing, bdan tiba2 dingin, badan

\section{Pola Sikap:afek:keamanan:yakin}

Tabel 13 Leksis "yakin"

24 10 langkah aja ga kuat,tp yakin pelan2 semua bisa walaupun

25 ct scan kepalanya krn sy yakin kepala sy ga kenapa2/ELT

Pola Sikap:afek:keamanan:percaya

Tabel 14 Leksis "percaya"

26 Jadi sakit hati/Kok gak ad yg percaya /Seolah2 aku ini mengada

27 persis/RM: Gak akan ad yg percaya krna mereka gak mengalami

Pola Sikap:penilaian:penghargaan social:normalitas:positif Tabel 15 Leksis "bahagia"

\begin{tabular}{llll}
\hline 28 & hanya pikiran...aku memilih & bahagia & aku memilih kuat/Janmoyes \\
29 & stop/cukup. Saya kuat saya & bahagia & dan saya sehat./GE: Terus \\
\hline
\end{tabular}

Pola Sikap:penilaian:penghargaan sosial:normalitas:negatif

Tabel 16 Leksis "aneh"

\begin{tabular}{llll}
\hline 30 & tapi luar biasa ngerasa yang & aneh aneh & sampe malemnya nyeri \\
31 & luar biasa ngerasa yang & aneh aneh. & sampe malemnya nyeri dada \\
\hline
\end{tabular}

Pola Sikap:penilaian:penghargaan social:kapasitas:positif

Tabel 17 Leksis "sehat"

$\begin{array}{llll}32 & \text { alhamdulillah lambung saya } & \text { sehat } & \text { tapi, karna anxiety nya } \\ 33 & \text { pikiran,sy bilang lambung sy } & \text { sehat } & \text { dan sy stop semua obat lambung }\end{array}$

Pola Sikap:penilaian:penghargaan social:kapasitas:negatif

Tabel 18 Leksis "sakit"

\begin{tabular}{lrll}
\hline 34 & proyektor pikiran. Tubuh yang & sakit & mencerminkan pikiran yang \\
35 & mencerminkan pikiran yang & sakit. & Percuma menjaga pola makan \\
\hline
\end{tabular}




\section{Pola Sikap:penilaian:penghargaan social:tenasitas:positif}

Tabel 19 Leksis "pasti"

36 /paru,saraf/OY: Smngat bu Pasti smbuh smngat/ELT: Semua hasilnya

37 BPK aj yg ngalamin...semangat pasti bisa melewati ny/AG: Maaf

\section{Sikap:penilaian:penghargaan social:tenasitas:negatif}

Tabel 20 Leksis "bingung"

38 sya itu/SM: Itu saya kadang

39 mf jorok..muntah muntah../JD bingung, penyakit apa iru namnya

bingung tiap hari cuma mkn wortel

\section{Sikap:penilaian:sanksi social:verasitas:positif}

Tabel 21 Leksis "jujur"

40 di kelarin PD nunda2 trs kita

jujur ktmu org modus2 ngbatin sendiri

41 mencari kesembuhan../JS: iyo

jujur saya pak didi./DS: Pasti

Pola sikap:penilaian:sanksi social:verasitas:negatif

Tabel 22 Leksis "bohong"

42 yg buruk kita pikirkan itu bohong dan gak ada bukti nyata

43 dan bisa melupakan pikiran bohong itu....okey teman?/MN: Okey

\section{Pola Sikap:penilaian:sanksi social:proprietas: positif}

Tabel 23 Leksis "wajar"

44 dan takut itu sesuatu yg wajar sebagai warning akan adanya

45 skrg jd berasa, tapi katanya wajar, ibaratnya kaya luka d kelupas

Pola Sikap:penilaian:sanksi social:proprietas:negatif

Tabel 24 Leksis "buruk"

46 sebabnya serangkaian perasaan buruk bakal terjadi pada kita bahwa

47 tak mampu mengalihkan pikiran buruk kita yg berupa imajinasi

\section{Pola Sikap:apresiasi:impak:positif}

48. lg santai dksih tenaga yg kuat, akhirya degdegan.klo gk di

49. melangkah 10 langkah aja ga kuat, sampe sy sedih bgt knp sy

\section{Pola Sikap:apresiasi:kualitas:positif}

\begin{tabular}{llll}
\hline 50. & masalh di perut/CT: Klu mau & bagus.. & yg terasa bgt..bikin temulawak \\
51. & NW: Sy baru mau minum ini & Bagus & nggak ya../CT: Ak baru tgl \\
\hline
\end{tabular}

\section{Pola Sikap:apresiasi:kualitas:negatif}

52. ato ssdah/SM: Tapi kalau dulu

53. krn gerd dan lambungnya
Tabel 27 Leksis "parah"

parah kak n sdh lnayan, ,kalau

parah bgt smpe dirawat,ga bisa 


\section{Pola Sikap:apresiasi:keseimbangan:positif}

Tabel 28 Leksis "seimbang"

\begin{tabular}{llll}
\hline 54. & mbak?/AG: IyA jdi kya yg gk & seimbang & klau liat/FN: Itu gra \\
55. & tidur makan dan olahraga & seimbang & /EML: untuk kekuatan fisik \\
\hline
\end{tabular}

Pola Sikap:apresiasi:keseimbangan:negatif

Tabel 29 Leksis "berantakan"

\begin{tabular}{llll}
\hline 56. & Itu yg buat hormon kita yg & berantakan, & $\lg$ santai malah di kasih \\
57. & anak2 jg enak maennya,cm klo & berantakan & sy suka seklian aja \\
\hline
\end{tabular}

\section{Pola Sikap:apresiasi:kompleksitas:positif}

\begin{tabular}{llcl} 
& & Tabel 30 & Leksis "pas" \\
\hline 58. & dr perut,suasana yg gk & pas, & lgsung perut kyk lemas,ujungya \\
59. & sisa 1 gelas ksh gula aren & pas & anget2.minumin/Ela (EL): Klo \\
\hline
\end{tabular}

\section{Pola Sikap:apresiasi:kompleksitas:negatif}

Tabel 31 Leksis "sulit"

\begin{tabular}{llll}
\hline 60. & dokter bersamaan......memang & sulit & tp tdk ada yg mustahil.. \\
61 & sangat menyiksa dan sangat & sulit & untuk bebas dari paniknya \\
\hline
\end{tabular}

Pola sikap:apresiasi:valuasi:negatif

Tabel 32 Leksis "buruk"

\begin{tabular}{llll}
\hline 62 & sebabnya serangkaian perasaan & buruk & bakal terjadi pada kita bahwa \\
63 & tak mampu mengalihkan pikiran & buruk & kita yg berupa imajinasi \\
\hline
\end{tabular}

\section{Pembahasan}

Apraisal Sikap dalam penelitian ini terbagi atas tiga subsistem yaitu Afek, Penghakiman/penilaian, dan Apresiasi. Afek (affect) merupakan sumber daya untuk mengungkapkan perasaan. Penilaian atau penghakiman (judgement) merupakan sumber daya untuk menilai karakter atau watak. Apresiasi (appreciation) merupakan sumber daya untuk menghargai nilai suatu benda.

Pemaparan setiap subsistem dalan sumber-sumber apraisal Sikap dilakukan untuk menjawab pertanyaan bagaimana apraisal Sikap dalam teks percakapan penyandang anxiety dan mengapa apraisal Sikap terbentuk demikian dalam teks percakapan penyandang anxiety? Pemaparan hasil analisis data dimulai dari subsistem sumber-sumber Afek, kemudian sumber-sumber Penilaian/Penghakiman, selanjutnya sumber-sumber Apresiasi, dan terakhir dominasi subsistem apraisal Sikap tersebut.

Berikut ini merupakan hasil perolehan analisis data dari teks percakanan antara para penyandang anxiety pada sumber-sumber Afek.

\section{Tabel 33 Sumber-sumber Afek dalam dialog penyandang anxiety}

\begin{tabular}{rlclllll}
\hline No & Positif & Jlh & Persts & & Negatif & Jlh & Persts \\
1 & ingin/hasrat & 399 & $18,25 \%$ & 8 & takut & 585 & $26,76 \%$ \\
2 & ceria & 40 & $1,83 \%$ & 9 & sengsara & 38 & $1,74 \%$ \\
3 & kasih & 83 & $3,80 \%$ & 10 & antipati & 7 & $0,32 \%$ \\
4 & menarik hati & 14 & $0,64 \%$ & 11 & bosan & 66 & $3,02 \%$ \\
5 & senang & 91 & $4,16 \%$ & 12 & tidak senang & 8 & $0,37 \%$ \\
\end{tabular}




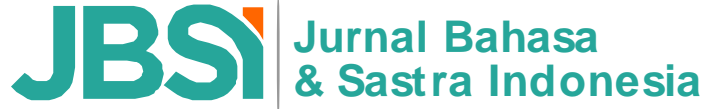

Volume: 1 | Nomor 1 | November 2021 | E-ISSN: 2809-238X | DOI: 10.47709/jbsi.v1i1.1394

\begin{tabular}{|c|c|c|c|c|c|c|c|}
\hline 6 & yakin & 310 & $14,18 \%$ & 13 & gelisah & 340 & $15,55 \%$ \\
\hline 7 & percaya & 139 & $6,36 \%$ & 14 & Heran & 66 & $3,02 \%$ \\
\hline & Total & 1.076 & $49,22 \%$ & & & 1.110 & $50,78 \%$ \\
\hline
\end{tabular}

Tabel 33 menggambarkan sumber-sumber afek:takut yang paling dominan di antara ke 14 subsistem Afek sebesar 26,76\%. Contoh subsistem takut dari sumber-sumber Afek yang memiliki makna negatif dapat dilihat pada leksis "cemas" dalam klausa perut kayak lemas, ujungya cemas cemas, tapi saya merasa uda mendingan.

Leksis cemas merupakan leksis yang memiliki makna negatif dalam subsistem sumber-sumber Afek. Leksis lainnya yang bermakna negatif dalam subsistem afek:takut, seperti "gemetar, (ke)takut(an), ngeri, khawatir, awas, ciut, gelisah, ngeri, sedih, sakit hati, menderita, tidak bahagia, murung, getir, gundah, sedu, terharu, dan tersentuh (perasaan)".

Sementara, sumber-sumber afek:ingin/hasrat yang bermakna positif sebesar 18,25\%, dominan kedua setelah subsistem afek:takut. Contoh subsistem "ingin/hasrat" dapat dilihat pada leksis "baik" pada klausa berikut ini. Hasil rontgen leher hasilnya baik jd mau lihat di kepala lagi.

Leksis lainnya yang termasuk kelompok sumber-sumber afek:ingin/hasrat yang bermakna positif adalah "saran, bisikan, anjuran, permintaan, menunggu, ingin, ceria, gembira, suka, cinta, sayang, beruntung, cerah, enak, girang, lega, nikmat, puas, riang, sejahtera, selamat, senang, suka cita, bahagia, tertawa, (me)rinduk(an), rindu".

Selain sumber-sumber leksis Afek yang mendominasi penggunaan leksis cemas yang bermakna negatif, sumber-sumber Sikap:Penghakiman/penilaian didominasi oleh sumber-sumber kapasitas (how capable) positif sebesar 26,94\% seperti yang terlihat pada Tabel 34. Sementara, sumber-sumber tenasitas negatif sebesar $13,56 \%$.

Tabel 34 Sumber-sumber Penghakiman/Penilaian dalam dialog penyandang anxiety

\begin{tabular}{|c|l|c|l|l|l|l|l|}
\hline No & Positif & Jlh & Persts & No & Negatif & Jlh & Persts \\
\hline 1 & normalitas & 348 & $20,52 \%$ & 6 & normalitas & 48 & $2,83 \%$ \\
\hline 2 & kapasitas & 457 & $26,94 \%$ & 7 & kapasitas & 154 & $9,08 \%$ \\
\hline 3 & tenasitas & 221 & $13,03 \%$ & 8 & tenasitas & 230 & $13,56 \%$ \\
\hline 4 & verasitas & 62 & $3,65 \%$ & 9 & verasitas & 7 & $0,41 \%$ \\
\hline 5 & proprietas & 157 & $9,25 \%$ & 10 & proprietas & 12 & $0,71 \%$ \\
\hline & Total & 1.245 & $73,41 \%$ & & & 451 & $26,59 \%$ \\
\hline
\end{tabular}

Leksis sehat dalam klausa Alhamdulillah lambung saya sehat tapi, karna anxiety nya merupakan penggunaan sumber-sumber penghakiman/penilaian:kapasitas yang memiliki nilai positif.

Selain leksis sehat, leksis yang menunjukkan penilaian:kapasitas adalah "giat, semangat, hebat, kuat, waras, lucu, pintar, cakap, pandai, seimbang, waras, ahli, pintar, cerdas, cakap, mampu, ulung, pandai, berhasil, dan periang".

Leksis penilaian/penghakiman negatif dalam teks percakapan para penyandang anxiety dapat dilihat dalam klausa Itu saya kadang bingung penyakit apa itu namnya yan termasuk dalam kelompok tenasitas (how dependable?). Leksis lainnya yang menunjukkan tenasitas negatif adalah "malu, buru-buru, lemah, sedih, nekat". 


\section{JBS Jumal anhese \& Sastra Indonesia}

Volume: 1 | Nomor 1 | November 2021 | E-ISSN: 2809-238X | DOI: 10.47709/jbsi.v1i1.1394

Pada subsistem apraisal Sikap, penggunaan leksis Afek:Takut negatif mendominasi penggunaannya dalam percakapan di antara para penyandang anxiety. Sementara, penggunaan leksis Penilaian/penghakiman:kapasitas positif yang mendominasi. Selanjutnya, penggunaan leksis Apresiasi pada Tabel 35 didominasi oleh Apresiasi:Kualitas positif sebesar 33,31\% sedangkan pada Apresiasi:Valuasi negatif sebesar 5,60\%.

Tabel 35 Sumber-sumber Apresiasi

\begin{tabular}{|c|l|c|l|l|l|l|l|}
\hline No & Positif & Jlh & Persts & No & Negatif & Jlh & Prest \\
\hline 1 & impak & 87 & $5,48 \%$ & & impak & 0 & 0 \\
\hline 2 & kualitas & 529 & $33,31 \%$ & & kualitas & 40 & $2,52 \%$ \\
\hline 3 & keseimbangan & 22 & $1,38 \%$ & & keseimbangan & 5 & $0,31 \%$ \\
\hline 4 & kompleksitas & 308 & $19,40 \%$ & & kompleksitas & 70 & $4,41 \%$ \\
\hline 5 & valuasi & 438 & $27,58 \%$ & & valuasi & 89 & $5,60 \%$ \\
\hline & Total & 1.384 & $87,15 \%$ & & & 204 & $12,85 \%$ \\
\hline
\end{tabular}

Penggunaan leksis Apresiasi:Kualitas positif "bagus" dalam klausa sebetulnya semua herbal bagus Bu saya minum jelly gamat. Sementara, penggunaan leksis Apresiasi:Valuasi yang memiliki nilai negatif dapat dilihat dalam klausa tak mampu mengalihkan pikiran buruk kita yg berupa imajinasi.

Dari paparan analisis data sumber-sumber Afek, Penilaian/penghakiman, dan Apresiasi, dapat diurut dominasi penggunaan leksis dalam subsistem apraisal Sikap, seperti yang dapat di lihat pada Tabel 36 berikut ini.

Tabel 36 Sumber-sumber apraisal Sikap dalam teks percakapan penyandang anxiety

\begin{tabular}{|c|c|c|c|c|c|c|}
\hline & \multicolumn{4}{|c|}{ Sumber-sumber apraisal Sikap } \\
\cline { 2 - 7 } & \multicolumn{2}{|c|}{ Afek } & \multicolumn{2}{c|}{ Penilaian } & \multicolumn{2}{c|}{ Apresiasi } \\
\hline $\begin{array}{c}\text { Penyandan } \\
\text { g Anxiety }\end{array}$ & 2186 & $39,96 \%$ & 1.696 & $31,00 \%$ & 1.588 & $29,03 \%$ \\
\hline
\end{tabular}

Dari Tabel 36 dapat disusun urutan dominasi penggunaan leksis oleh para penyandang anxiety yaitu Afek ^ Penilaian ^ Apresiasi. Dengan demikian, Tabel 36 menunjukkan bahwa sumber-sumber apraisal Sikap yang paling dominan digunakan para penyandang anxiety dalam teks percakapan adalah Afek dibandingkan dengan kedua sumber subsistem apraisal Sikap lainnya, yaitu Penilaian dan Apresiasi.

Dari Sumber-sumber Afek, leksis yang paling dominan digunakan adalah subsistem Afek:takut sebesar 26,76 persen dibandingkan dengan ketigabelas subsistem sumber-sumber leksis Afek lainnya.

Fenomena ini mengindikasikan bahwa subsistem Afek lebih dominan digunakan dalam berkomunikasi di antara sesama penyandang anxiety untuk menunjukkan ekspresi emosi dan perasaannya. Dalam konteks ini, mereka menyatakan perasaan takut yang berisikan leksis cemas, seperti yang terlihat pada klausa Masih terus berjuang melawan cemas.

Sumber-sumber penggunaan leksis Afek dalam teks percakapan tulisan dari para penyandang anxiety pada grup media whatsApp BBC mengindikasikan para penyandang anxiety paling dominan menunjukkan ekspresi emosi dan perasaan yang negatif berupa ketakutan atau kecemasan seperti yang digambarkan di atas. Ini terlihat dalam setiap klausa yang mereka tulis, saat mereka mendiskusikan masalah kesehatan mereka antara sesama grup anggota Bye-Bye Cemas (BBC). 
Bahwa ketakutan dan kecemasan yang dirasakan oleh penyandang anxiety sangat menyiksa kehidupan mereka direalisasikan dalam leksis yang menunjukkan perasaan takut mereka melalui tulisannya di grup WhatsApp chat saat mereka mengungkapkan apa yang terjadi kepada diri mereka dan bagaimana cara penyembuhannya.

Di samping perasaan takut dan cemas dalam percakapan mereka di WhatsApp Chat BBC yang bernuansa negatif, ditemukan juga ungkapan perasaan yang positif. Keinginan dan hasrat mereka ingin sembuh dari penyakit yang tubuh dan pikiran mereka tergambar ketika para penyandang anxiety menggunakan banyak leksis baik.

Leksis baik seperti yang terlihat dalam klausa berikut ini Bersyukur ketemu dokter yang baik hati menggambarkan harapan kesembuhan yang diingin oleh para penyandang anxiety dengan harapan mereka mendapat penanganan dan pelayanan dari dokter yang baik.

Selanjutnya, tatanan subsistem Penghakiman/penilaian sebagai area yang menunjuk kepada atitud seseorang kepada orang lain serta perilaku dan karakternya. Ditemukan bahwa sumber-sumber Penghakiman berada pada urutan kedua dominasi penggunaan bahasa evaluatif setelah sumber-sumber Afek.

Atitud yang positif diperlihatkan juga oleh para penyandang anxiety bahwa mereka menilai pengalaman sakit yang mereka rasakan dan berbagai cara dan saran untuk kesembuhan yang diberikan oleh kawankawan mereka sesama penyandang anxiety menerbitkan ungkapan yang lebih dominan positif daripada negatif. Hal ini dapat dilihat dari klausa alhamdulillah lambung saya sehat tapi, karna anxiety nya... Leksis sehat dengan demikian menunjukkan sumber-sumber penghakiman yang positif.

Selain leksis yang positif dalam subsistem penghakiman, sumber-sumber negatif juga mewarnai penggunaan leksisnya, seperi penggunaan leksis bingung dalam klausa Itu saya kadang bingung, penyakit apa itu namanya.

Tatanan yang ketiga adalah subsistem Apresiasi yang merupakan area makna yang merujuk pada evaluasi kita terhadap benda atau sesuatu, khususnya benda-benda yang kita buat dan penampilanpenampilan yang kita lakukan, termasuk juga fenomena alam. Ditemukan subsistem Apresiasi:kualitas merupakan yang paling rendah dominasinya dibandingkan dengan dua subsistem lainnya yaitu Afek dan Penghakiman/penilaian.

Subsistem Apresiasi:Kualitas dengan leksis bagus dapat dilihat pada klausa Kasih gula aren....itu bagus untuk darah rendah. Leksis bagus dalam konteks klausa ini bermakna positif karena diinterpretasikan membawa kebermanfaatan yang baik bagi tubuh.

Selain nilai positif, apresiasi:valuasi negatif juga dapat dilihat dari klausa sebabnya serangkaian perasaan buruk bakal terjadi pada kita. Leksis buruk memberi gambaran pada sesuatu yang diapresiasi tidak bagus.

Tabel 37 Rekapitulasi penggunaan leksis apraisal Sikap dalam teks percakapan.

\begin{tabular}{|l|l|l|l|l|}
\hline Sikap & \multicolumn{2}{|c|}{ Positif } & \multicolumn{2}{c|}{ Negatif } \\
\hline Afek & 1.076 & $49,22 \%$ & 1.110 & $50,78 \%$ \\
\hline Penghakiman & 1.384 & $87,15 \%$ & 204 & $12,85 \%$ \\
\hline Apresiasi & 1.245 & $73,41 \%$ & 451 & $26,59 \%$ \\
\hline
\end{tabular}


Dari ketiga paparan subsistem Sikap dari Apraisal yang dikaji dalam penelitian ini berdasarkan Tabel 45 di atas mengindikasikan bahwa leksis-leksis apraisal Sikap yang digunakan dalam percakapan tulisan dari grup WhatsApp BBC menggambarkan dominasi menggunakan leksis-leksis positif dibandingkan dengan leksis-leksis negatif.

Logikanya, keluhan-keluahan penyandang anxiety akan menunjukkan penggunaan leksis negatif yang dominan. Namun, data penelitian percakapan para penyandang anxiety menunjukkan perbedaan. Dominasi leksis-leksis positif menggambarkan bahwa orang-orang penyandang anxiety lebih banyak yang memberi saran-saran yang positif kepada kawan-kawan yang mengeluh tentang keluhan gangguan kesehatan mereka yang ada dalam kelompok BBC itu dibandingkan dengan jumlah leksis dari orangorang yang mengeluh tentang penyakit mereka.

\section{Kesimpulan}

Berdasarkan analisis data dapat disimpulkan sebagai berikut:

1. penggunaan sumber-sumber subsistem Afek dalam apraisal Sikap paling dominan dibandingkan dengan kedua subsistem lainnya yaitu Penghakiman/Penilaian dan Apresiasi;

2. penggunaan sumber-sumber "takut" bernilai negatif paling dominan dalam subsistem Afek, kemudian diikuti sumber-sumber "ingin/hasrat" yang bernilai positif. Setelah itu, penggunaan sumber-sumber "kapasitas" bernilai possitif paling dominan dalam subsistem Penilaian/Penghakiman, kemudian diikuti sumber-sumber "tenasitas" yang bernilai negatif. Penggunaan sumber-sumber "kualitas" bernilai positif paling dominan dalam subsistem Apresiasi, kemudian diikuti sumber-sumber "valuasi" yang bernilai negatif. Dominasi penggunaan leksis subsistem Afek dalam percakapan para penyandang anxiety di WhatsApp BBC pada umumnya disebabkan para penyandang anxiety berbicara tentang ekspresi emosi dan perasaan mereka berkaitan dengan penyakit cemas dan takut yang menerpa mereka. Selanjutnya, mereka berharap ada solusi atau jalan keluarnya dari kawan-kawan satu grup penyandang anxiety tentang penyakit yang mereka derita.

\section{Referensi}

Anandi, Rizki Parahita. 2017. Tingkat Kecemasan Berbicara Bahasa Arab di Kalangan Pelajar Sebuah Universitas di Jawa Tengah dalam Lisania: Journal of Arabic Education and Literature Vol.1, No.2, 2017, p.1-19.

Andri. 2017. Segala sesuatu tentang Cemas. Jakarta: Meodik Publishing.

Bednarek, Monica. 2008. Emotion Talk across Corpora. London: Palgrave Macmillan.

Bednarek, Monica. 2009. 'Language patterns and Attitude' Functions of Language 16:2 (2009), 165-192.

Bednarek, Monika. 2006. Evaluation in Media Discourse: analysis of a newspaper corpus. London: Continuum. 
Bednarek, Monika. 2007. "Local Grammar and Register Variation: Explorations in Broadsheet and Tabloid Newspaper Discourse", ELR Journal http://ejournals.org.uk/ELR/article/2007/1 (4 September, 2007).

Biber, D., S.Johansson, G. Leech, S.Conrad, and E.Finegan, E. 1999. Longman Grammar of Spoken and Written English. London: Longman.

Biber, Douglas \& Edward Finegan. 1989. 'Style of Stance in English: Lexical and Grammatical marking of Evidentiative and affect'. Text 9, 93-124

Biber, Douglas \& Edward Finegan.1988. 'Adverbial Stance Types in English'. Discourse Processes 11, $1-34$

Biber, Douglas. 2006. 'Stance in spoken and written university registers'. Journal of English for Academic Purposes 5, 97-116

Biber, Douglas. 2009. A Corpus-Driven Approach to Formulaic Language in English Multi Word Pattern. John Benjamins Company.

Brown, Gillian \& George Yule. 1983. Discourse Analysis. Cambridge: Cambridge University Press.

Conrad, S. and D. Biber. 2000. 'Adverbial Making of Stance in Speech and Writing' dalam Susan Hunston \& Geoff Thompson. 2000. Evaluation in Text: Authorial Stance and the Construction of Discourse. Oxford: Oxford University Press.

Du Bois, J. 2007. 'The Stance triangle', dalam Englebretson, R. (ed). Stance Taking in Discourse. Amsterdam: Benjamin 130-182

Halliday, M.A.K \& Christian M.I.M.Matthiessen. 2004/2014. Introduction to Functional Grammar. Third edition. London: Arnold.

Halliday, M.A.K. 1985/1994. Introduction to Functional Grammar. London: Arnold.

Hunston, S. 1994. 'Evaluation and organisation in academic discourse', dalam M.Coulthard (ed.) Advances in Written Text Analysis. London: Routledge.191-218.

Hunston, Susan \& Geoff Thompson. 2000. Evaluation in Text: Authorial Stance and the Construction of Discourse. Oxford: Oxford University Press.

Macken-Horarik, M. and Martin, J.R. eds. 2003. 'Apraisal'. Special issue of Text 23(2).

Martin, J.R. \& David Rose. 2003/2007. Working with Discourse: Meaning beyond the Clause. London: Continuum.

Martin, J.R. \& White, P.R.R. 2005. Language of Evaluation: Appraisal in English. Basing stoke, UK: Palgrave.

Martin, J.R. 2004. 'Mourning: How we get aligned.' Discourse and Society 15.2-3; 321-344.

Martin. J.R. 2000. 'Beyond exchange: Appraisal systems in English.' dalam S. Hunston and G. Thompson, ed, Evaluation in text: Authorial stance and the construction of discourse, Oxford University Press, Oxford pp. 142-175. 


\section{JBS Jurna A Batase \\ JBS/ ssatata hanonsia}

Volume: 1 | Nomor 1 | November 2021 | E-ISSN: 2809-238X | DOI: 10.47709/jbsi.v1i1.1394

Muslimin, Khoirul. 2013. Faktor-Faktor yang Mempengaruhi Kecemasan berkomunikasi di depan Umum. Jurnal interaksi, Vol II No 2, Juli 2013, 42-52.

Nazhira, Rusyda., Silvana Sinar, dan Suriyadi. 2017. Apraisal Sikap dalam Teks Berita Surat Kabar Nasional. JURNAL TUTUR Vol.2, No.1 Februari 2016, ISSN 2442-3475.

Nevid, Jeffrey S., Spencer A. Rathus, Beverly Greene. 2014. Abnormal psychology in a changing world, Ninth Edition. p.158-159. Boston: Pearson Education, Inc.

Read, J dan Carroll, J. 2012. "Annotating expressions of appraisal in English”. Language Resources \& Evaluation, Vol. 46, pp. 421 - 447.

Siregar, Bahren Umar. 2005. Menjajaki Bahasa Evaluatif: Evaluasi, Sikap Mental, dan Apraisal. Medan: Kumpulan Makalah PLU-3.

Suriyadi \& Silvana Sinar. 2017 Apraisal Sikap dalam Teks Editorial Surat Kabar di Medan yang dimuat pada Proceedings of Atma Jaya Conference on Corpus Studies di Jakarta.

Thompson, Geoff \& Susan Hunston. 2000. "Evaluation: An Introduction” dalam Hunston, Susan \& Geoff Thompson, ed. Evaluation in Text: Authorial Stance and the Construction of Discourse. Oxford: Oxford University Press.

White, Peter R. 1998. Telling Media Tales: the news story as rhetoric. Unpublish Ph.D Dissertaion, University of Sydney (www.grammatics.com/Apraisal) 